\title{
HEMORRHAGIC POST PARTUM: SYOK HEMORRHAGIC EC LATE HEMORRHAGIC POST PARTUM
}

\author{
Primadella Fegita ${ }^{1}$, Pom Harry Satria ${ }^{2}$
}

\begin{abstract}
Abstrak
Pendahuluan: Kematian ibu terjadi sebagai akibat dari komplikasi selama dan setelah kehamilan dan persalinan. Sebanyak $80 \%$ kematian ibu di dunia disebabkan perdarahan berat (terutama perdarahan setelah persalinan), infeksi, tekanan darah tinggi selama kehamilan. Menurut data Kementrian Kesehatan tahun 2010, perdarahan menempati presentasi tertinggi penyebab kematian ibu di Indonesia yaitu sebesar 28\%. Laporan Kasus: Seorang wanita, 31 tahun, datang dengan penurunan kesadaran dan perdarahan banyak dari kemaluan sejak 3 jam sebelum masuk rumah sakit, nadi teraba cepat dan halus. Pasien sebelumnya melahirkan di rumah ditolong bidan 10 hari yang lalu, kakak anak lahir 30 menit setelah anak lahir dan kesan diakui bidan lengkap. Diagnosa akhir pada pasien ini Syok Hemoragik Teratasi ec Late HPP ec Sisa plasenta + Anemia Sedang (Hb 7,0 gr/dl). Simpulan: Pada kasus ini membuktikan bahwa HPP masih menjadi hal yang menakutkan sebagai penyebab kematian ibu. Dalam hal ini dirasa perlu adanya alur rujukan untuk kasus emergensi, yaitu pengelompokkan kasus pada persalinan dengan komplikasi segera dilakukan pelaporan kasus ke DINKES untuk rujukan ke RS. Setelah perawatan di RS selesai, perawatan lanjutan atau postnatal care dilakukan sesuai jadwal. Pasien diantar kembali setelah selesai perawatannya, dan hasil rujukan dilaporkan kembali ke hotline Dinkes Kabupaten/kota.
\end{abstract}

Kata kunci: HPP, kematian ibu

\section{Abstract}

Introduction: Maternal death occurs as a result of complications during and after pregnancy and childbirth. As many as $80 \%$ of maternal deaths in the world are caused by heavy bleeding (especially bleeding after childbirth), infections, high blood pressure during pregnancy. According to data from the Ministry of Health in 2010, bleeding was the highest presentation of maternal mortality in Indonesia, which was 28\%. Case Report: A woman, 31 years old, came with a decrease in consciousness and heavy bleeding from the genitals 3 hours before hospitalization, pulse felt quickly and smooth. Patients previously delivered at home were helped by a midwife 10 days ago, older siblings born 30 minutes after the child was born and the impression that the midwife was fully recognized. Final diagnosis in this patient Hemorrhagic shock Overcoming ec Late HPP ec Placental residue + Moderate anemia (Hb $7.0 \mathrm{gr} / \mathrm{dl}$ ). Conclusion: In this case prove that HPP is still a frightening thing as a cause of maternal death. In this case it is felt necessary to have a referral pathway for emergency cases, namely the grouping of cases in labor with complication of immediately reporting cases to DINKES for referral to the hospital. After treatment at the hospital is complete, continued treatment or postnatal care is carried out on schedule. The patient is resettled after completion of treatment, and the referral results are reported back to the District / city Health Office hotline.

Keywords: Hemorhagic Post Partum, Maternal Death

Affiliasi penulis: 1. PPDS Obstetri dan Ginekologi Fakultas Kedokteran Universitas Andalas/ RSUP Dr. M. Djamil Padang; 2. Bagian Obstetri dan Ginekologi Fakultas Kedokteran Universitas Andalas/ RSUP Dr. M. Djamil. Korespondensi: Primadella Fegita, Email: dellafegiita@yahoo.co.id Telp: 085265808389

\section{PENDAHULUAN}

Indikator yang digunakan untuk menilai derajat kesehatan masyarakat yang terpenting adalah Angka Kematian Ibu (AKI). AKI menggambarkan jumlah wanita yang meninggal dari suatu penyebab 
kematian terkait dengan gangguan kehamilan atau penanganannya (tidak termasuk kecelakaan atau kasus insidentil) selama kehamilan, melahirkan dan dalam masa nifas (42 hari setelah melahirkan) tanpa memperhitungkan lama kehamilan per 100.000 kelahiran hidup. ${ }^{1}$

Menurut data dari WHO setiap hari di dunia terjadi 800 ibu meninggal akibat kehamilan dan melahirkan dan sebanyak sembilan puluh sembilan persen (99\%) kematian tersebut terjadi di negara berkembang. ${ }^{2,3}$

Menurut Badan Pusat Statistik (BPS) pada tahun 2012 menunjukkan bahwa Angka Kematian Ibu melonjak dari 228 menjadi 359 per 100 ribu kelahiran yang menjadikan Indonesia sebagai negara dengan AKI terburuk dari negara-negara miskin di Asia. ${ }^{4,5}$

Angka ini juga masih jauh dari target dalam

Millenium Development Goals (MDGs) yaitu menurunkan angka kematian ibu hingga 102 dari 100.000 kelahiran hidup pada tahun 2015 yang pada akhirnya tidak tercapai. Target-target dalam MDGs ini kemudian dilanjutkan dalam bentuk program pembangunan global selanjutnya yang dikenal dengan Sustainable Development Goals (SDGs). Dalam program baru ini, angka kematian ibu ditargetkan menurun hingga mencapai 306 per 100.000 kelahiran hidup di tahun 2019 dan 70 per 100.000 kelahiran hidup pada tahun 2030 mendatang. ${ }^{5}$

Kematian ibu terjadi sebagai akibat dari komplikasi selama dan setelah kehamilan dan persalinan. Sebanyak $80 \%$ kematian ibu di dunia disebabkan perdarahan berat (paling sering perdarahan setelah persalinan), infeksi, tekanan darah tinggi selama kehamilan (pre-eklampsia dan eklampsia) serta aborsi yang tidak aman. 2,4 Perdarahan postpartum adalah penyebab utama kematian ibu di negara berkembang dan penyebab primer dari hampir seperempat dari seluruh kematian ibu secara global. Perdarahan postpartum adalah perdarahan yang terjadi setelah partus (persalinan), sebanyak $500 \mathrm{ml}$ pada persalinan per vaginam atau lebih dari $1000 \mathrm{ml}$ pada seksio sesarea. 6,7

Persalinan terbagi dalam tiga tahap/kala.

Kala 1 dimulai dari awal kontraksi uterus hingga pembukaan serviks penuh $(10 \mathrm{~cm})$ sehingga memungkinkan kepala janin lewat. Kemudian pada kala 2 terjadi kelahiran bayi lengkap dengan usaha dorongan secara aktif dari ibu, dilanjutkan dengan kala 3 yang berakhir dengan pengeluaran plasenta. Perdarahan postpartum biasanya terjadi setelah kala 3 persalinan. $^{7}$

Perdarahan postpartum primer disebabkan oleh 4T, yaitu atonia uteri (Tonus), retensio plasenta dan bekuan darah (Tissue), lesi/robekan jalan lahir (Trauma), dan gangguan pembekuan darah (Thrombin). 1,2,3,6

\section{a. Atonia Uteri}

Atonia uteri merupakan keadaan dimana otot uterus (miometrium) gagal berkontraksi pada tahap ke-3 persalinan, yaitu setelah bayi dilahirkan, sehingga perdarahan dari tempat perlekatan arteri dan vena spiral plasenta terus terbuka. Kondisi bahwa 1/5 dari curah jantung ibu hamil yaitu sekitar $1000 \mathrm{ml} / \mathrm{menit}$ memasuki sirkulasi uteroplasenta saat persalinan membuat perdarahan postpartum karena atonia uteri ini dapat menghilangkan banyak darah ibu dalam waktu singkat. Hal ini yang membuat atonia uteri menjadi penyebab paling sering kematian ibu oleh perdarahan postpartum yaitu sekitar $75-90 \%{ }^{6}$

Penyebab pasti disfungsi kontraksi pada uterus ini masih belum diketahui secara pasti. Tetapi pada banyak wanita hamil, atonia uteri paling tidak dapat diantisipasi dengan baik pada kehamilan lanjut. Terdapat beberapa faktor risiko yang berhubungan dengan atonia uteri. Paritas tinggi sudah lama diketahui sebagai salah satunya, dimana insiden perdarahan postpartum meningkat dari 0,3 pada paritas rendah menjadi 1,9 pada paritas tinggi, dan 2,4 pada paritas 7 kali atau lebih. ${ }^{8}$

Uterus yang terdistensi berlebihan juga cenderung hipotonia setelah persalinan oleh karena itu ibu hamil dengan janin besar, janin multipel, atau polihidramnion memiliki risiko tinggi. Abnormalitas proses persalinan (distosia) juga cenderung atonia. Sama seperti induksi persalinan dengan prostaglandin atau oksitoksin juga sering disertai atonia. ${ }^{6}$

b. Retensio Plasenta

Pada kala tiga persalinan, miometrium berkontraksi mengikuti penyusutan rongga uterus setelah lahirnya bayi. Penyusutan ukuran ini menyebabkan berkurangnya ukuran tempat perlekatan plasenta. Karena tempat perlekatan menjadi semakin 
kecil, sedangkan ukuran plasenta tidak berubah maka plasenta akan terlipat, menebal, dan kemudian terlepas dari dinding uterus. Setelah lepas, plasenta akan turun ke bagian bawah uterus atau ke dalam vagina. ${ }^{8}$

c. Robekan Jalan Lahir

Proses persalinan selalu terkait dengan trauma jalan lahir termasuk uterus, serviks, vagina, dan perineum. Cedera yang didapat saat persalinan dapat berkisar dari robekan mukosa minor hingga laserasi yang menyebabkan perdarahan yang mengancam jiwa. ${ }^{4}$ Robekan yang terjadi bisa ringan (lecet, laserasi), luka episiotomi, robekan perineum spontan derajat ringan sampai ruptur perinei totalis (sfingter ani terputus), robekan pada dinding vagina, forniks uteri, serviks, daerah sekitar klitoris dan uretra serta bahkan yang paling berat yaitu ruptur uteri. ${ }^{7}$

\section{d. Gangguan Pembekuan Darah}

Kelainan pembekuan darah kongenital dan didapat berperan signifikan pada kejadian perdarahan postpartum primer tetapi jarang terjadi hanya sekitar $3 \%$. Penyakit von Willebrand merupakan contoh penyakit koagulopati yang penting yang dapat meningkatkan risiko perdarahan postpartum. ${ }^{6}$ Gangguan pembekuan darah baru dicurigai sebagai kausal apabila penyebab yang lain telah disingkirkan dan disertai adanya riwayat pernah mengalami hal yang sama pada persalinan sebelumnya. ${ }^{8}$

Sebagian besar kasus kesakitan dan kematian ibu di Indonesia disebabkan oleh perdarahan postpartum dimana sebagian besar disebabkan oleh atonia uteri dan retensio plasenta yang sebenarnya dapat dicegah dengan melakukan manajemen aktif kala tiga. ${ }^{6}$

Keuntungan-keuntungan manajemen aktif kala tiga, yaitu :7,8

1) Persalinan kala tiga yang lebih singkat

2) Mengurangi jumlah kehilangan darah

3) Mengurangi kejadian retensio plasenta

\section{Gejala Klinis}

Seorang wanita hamil yang sehat dapat kehilangan darah sebanyak $10 \%$ dari volume total tanpa mengalami gejala-gejala klinik yang nyata. Gejala klinik baru tampak apabila kehilangan darah telah mencapai $20 \% .^{9}$
Perdarahan tidak hanya terjadi pada mereka yang memiliki faktor risiko tapi pada setiap persalinan kemungkinan terjadi perdarahan selalu ada. Jika perdarahan terus berlanjut akan menimbulkan tandatanda syok dengan gambaran klinisnya berupa perdarahan terus-menerus dan keadaan pasien secara berangsur-angsur menjadi jelek. Denyut nadi menjadi cepat dan lemah, tekanan darah menurun, pasien berubah pucat dan ekstrimita dingin, serta nafas menjadi sesak dan terengah-engah.9,10

\section{Diagnosis}

Berdasarkan definisi dari perdarahan postpartum yaitu perdarahan yang terjadi segera setelah partus (persalinan) ${ }^{1}$, sebanyak $500 \mathrm{ml}$ pada persalinan per vaginam atau lebih dari $1000 \mathrm{ml}$ pada seksio sesarea. 2,3 Cara yang paling tepat untuk menentukan apakah seseorang mengalami perdarahan postpartum adalah dengan menghitung kehilangan darah yang terjadi. Hal ini dapat dilaksanakan dengan cara mengukur atau memperkirakan jumlah darah yang hilang saat persalinan. ${ }^{10}$

\section{KASUS}

Seorang Pasien wanita usia 31 tahun datang ke IGD RSUD Dhamasraya dengan keluhan keluar darah yang banyak dari kemaluan sejak 3 jam sebelum masuk rumah sakit, darah berwarna merah kehitaman, membasahi 3 kain panjang +3 pembalut, nyeri perut ada. Sebelumnya pasien melahirkan di rumah, ditolong bidan, 10 hari yang lalu, BB anak 3900 gr, anak langsung menangis. Plasenta lahir 20 menit kemudian kesan diakui oleh bidan lengkap. Selama masa nifas, keluar darah berbongkah berwarna merah segar seperti darah haid, dan tidak berbau. Riwayat demam tidak ada.

Dari pemeriksaan fisik didapatkan Keadaan umum sedang,kesadaran composmentis kooperatif,tekanan darah $80 / 40 \mathrm{mmH}$,nadi : 98x/menit,nafas:26x/menit, suhu: $38^{\circ} \mathrm{C}$

PemariksaanAbdomen didapatkan:

- Inspeksi : Tampak perut sedikit membuncit

- Palpasi : Fundus uteri teraba 1 jari bawah pusat, kontraksi uterus kurang baik, nyeri tekan $(+)$, nyeri lepas (-), defans muskular (-)

- Perkusi : timpani 
- Auskultasi: bising usus (+) normal

Genitalia:

Inspeksi : - vulva dan uretra tenang -Tampak darah berwarna merah kehitaman bergumpal dari vagina Inspekulo:

Vagina: tumor (-), laserasi (-), fluksus (+) darah warna merah kehitaman menumpuk di fornix posterior

Portio: multípara, sebesar jempol kaki, tumor (-), laserasi (-), fluksus (+) mengalir aktif dari kanalis servikalis, OUE terbuka 3-4 cm. Didapatkan kesan syok hemoragik ec Late HPP ec susp sisa placenta. Dilakukan pemberian IVFD RL guyur 2 kolf, antibiotik, dan anti perdarahan.

Pukul 14.00 WIB didapatkan keadaan pasien mulai stabil dengan kesan syok hemoragik teratasi ec Late HPP ec susp sisa plasenta + anemia sedang dan direncanakan untuk kuretase setelah perbaikan KU. Tanggal 15 Februari 2016 dilakukan kuretase dengan kesan adanya sisa plasenta.Pasien direncanakan pulang keesok harinya dan diminta untuk control ke poliklinik RSUD Dhamasraya.

\section{PEMBAHASAN}

Telah dirawat seorang pasien wanita umur 31 tahun dengan diagnosa Syok Hemoragik teratasi ec Late HPP ec susp sisa plasenta + Anemia sedang. Diagnosa ditegakkan berdasarkan anamnesis, pemeriksaa fisik dan pemeriksaan penunjang.

Keluhan utama pasien berupa keluar darah yang banyak dari kemaluan sejak 3 jam sebelum masuk rumah sakit. Kondisi pasien saat di IGD, dalam keadaan syok hemoragik akibat perdarahan yang dialami oleh pasien, dimana terjadi penurunan tekanan darah hingga $80 / 40 \mathrm{mmHg}$, takikardi, takipneu, dan akral pasien yang teraba dingin, sehingga pada tahap awal dilakukan resusitasi cairan menggunakan cairan kristaloid RL $500 \mathrm{cc}$, diguyur. Hal ini sesuai dengan teori yang menyebutkan bahwa syok hemoragik dalah konsisi syok yang disebabkan oleh perdarahan yang banyak, dimana syok disebabkan gangguan sirkulasi darah ke jaringan sehingga tidak dapat memnuhi kebutuhan oksigen dan nutrisi jaringan dan tidak mampu mengeluarkan hasil metabolism. Gejala yang muncul pada pasien syok berupa hipotensi, nadi cepat dan halus, pucat, keringat dingin, sianosis jari-jari, sesak nafas, gelisah, dan oliguria Kemudian dilakukan pemantauan dalam 30 menit kemudian, terjadi perbaikan dari keadaan pasien, tekanan darah pasien naik menjadi 100/ $70 \mathrm{mmHg}$. Diketahui pasien berada dalam masa nifas dimana sebelumnya pasien melahirkan seorang bayi laki-laki 10 hari yang lalu di rumah ditolong oleh bidan. Hal ini mengindikasikan bahwa perdarahan yang dialami ibu erat kaitannya dengan proses persalinan yang ia jalani. Perdarahan pasca persalinan atau perdarahan postpartum berdasarkan onset terjadinya terbagi menjadi 2, yaitu early hemorrhagic postpartum dan late hemorrhagic postpartum. Kasus ini sesuai dengan definisi late hemorrhagic postpartum atau perdarahan postpartum sekunder, dimana perdarahan terjadi lebih dari 24 jam hingga 12 minggu postpartum.

Keluhan ini juga diikuti keluhan nyeri perut, dan badan terasa lemah. Dari pemeriksaan fisik didapatkan tekanan darah pasien 100/70 $\mathrm{mmHg}$, dan suhu $39,3^{\circ} \mathrm{C}$. Pemeriksaan mata didapatkan konjungtiva anemis +/+. Dari palpasi abdomen didapatkan tinggi fundus uteri masih 1 jari dibawah pusat, dan nyeri tekan (+). Keadaan ini mengindikasikan masih adanya jaringan dalam uterus yang menyebabkan uterus tidakr mengecil menjadi ukuran normal. Dari inspeksi genitalia tampak darah mengalir dari vagina, kemudian dilakukan inspekulo dan tampak darah mengalir dari portio, dan tumpukan darah di forniks posterior. Keadaan ini menunjukkan bahwa perdarahan aktif berasal dari dalam rongga uterus melalui kanalis servikalis. Dari hasil USG tampak sisa plasenta masih ada dalam uterus, yang menunjukkan bahwa sumber perdarahan yang terjadi berasal dari sisa plasenta tersebut.

Pada kasus ini, setelah dilakukan perbaikan keadaan umum, dengan dilakukannya transfusi darah 4 unit, dan tidak ditemukan keadaan syok pada pasien, kemudian dilakukan pemeriksaan USG untuk melihat sisa plasenta dan selanjutnya pasien direncanakan untuk kuretase. Setelah dilakukan kuretase pada pasien, dan berhasil dikeluarkan jaringan $\pm 150 \mathrm{cc}$, dan perdarahan selama tindakan \pm 100 cc, jumlah perdarahan pervaginam minimal, dan telah dilakukan pemeriksaan $\mathrm{Hb}$ post transfuse, dengan hasil $\mathrm{Hb} 11,4 \mathrm{~g} / \mathrm{dl}$, dan pasien diperbolehkan pulang dengan pengobatan yang diberikan untuk pasien berupa Cefixime, Asam mefenamat, Metyl ergometrin, Vitamin C, dan SF. 


\section{SIMPULAN}

Pada kasus ini, seharusnya diberikan KIE (komunikasi, informasi dan edukasi) tidak hanya kepada pasien, namun juga kepada suami pasien, keluarga, masyarakat serta tenaga kesehatan yang menolong persalinan. Sehingga angka morbiditas maternal dapat ditekan.

\section{DAFTAR PUSTAKA}

1. Cunningham FG. Obstetrical Hemorrhage. In: Cunningham FG, Lenovo KJ,Bloom SL, Dashe JS, Hoftman BL, Casey BM, Spong CY, editors. Obstetri Williams. Ed 23. Jakarta: EGC; 2009. Hal.755.

2. World Health Organization. Guiding principles on feeding nonbreastfed children 6 to 24 months of age. Geneva: World Health Organization; 2005.

3. Mochtar, R .Sinopsis Obstetri. Penerbit Buku Kedokteran. Jakarta: EGC; 2002. Hal 15.

4. Badan Pusat Statistik (BPS), [Indonesia], Badan Koordinasi Keluarga Berencana Nasional (BKKBN), Departemen Kesehatan, dan Macro Internasional. 2012.

5. Kementerian Kesehatan (Kemenkes) [Indonesia]. Situasi Kesehatan Ibu. Jakarta, Indonesia: Kemenkes. 2014.

6. Coker A, Oliver R. Definitions and classifications (B-Lynch C, Keith L, Lalonde A, Karoshi M editors). A Textbook of Postpartum Hemorrhage United Kingdom: Sapiens Publishing; 2006. Hal.130.

7. Prawirohardjo S. IImu Kebidanan. Jakarta: Penerbit Bina Pustaka; 2008. Hal.89.

8. Sulaiman S. IImu Kesehatan Reproduksi: Obstetri Patologi. Jakarta: EGC; 2010. Hal.175.

9. Kavle J.A. Association Between Anaemia During Pregnancy and Blood Loss at and after Delivery among Women with Vaginal Births. Journal of obstetrics and gynaecology. 2008; 240.

10. Borton C. Gravidity and Parity Definitions and their Implications in Risk Assessment. Austria: J Gen Intern Med; 2008. 